\title{
SYRINGOCYSTADENOMA PAPILLIFERUM (DEEP SEATED HORIOSTOMATOUS): A CASE REPORT
}

\author{
Paudel $D^{1}$, Midha A 2 , Samdurkar A ${ }^{3}$, Kumar A
}

\section{ABSTRACT}

Syringocystadenoma papilliferum (SCAP) is a rare benign adenexal tumor that frequently shows apocrine differentiation. SCAP usually occurs in the head and neck region in the children. Here in we report a case of 22 years female with SCAP occurring in deeper portion of the neck. The clinical, histopathological features and differential diagnosis of SCAP are also described.

KEYWORDS: Neck, Syringocystadenoma papilliferum, Adenexal

1. Post Graduate Resident, Department of Pathology, Universal College of Medical Sciences \& Teaching Hospital, Bhairahawa, Nepal

2. Post Graduate Resident, Department of Surgery, Universal College of Medical Sciences \& Teaching Hospital, Bhairahawa, Nepal

3. Professor, Department of Pathology, Universal College of Medical Sciences \& Teaching Hospital, Bhairahawa, Nepal

4. Professor, Department of Surgery, Universal College of Medical Sciences \& Teaching Hospital, Bhairahawa, Nepal

\author{
For correspondence \\ Dr. Deliya Paudel \\ Post Graduate Resident \\ Department of Pathology, \\ Universal College of Medical Sciences \& Teaching Hospital, \\ Bhairawa, Nepal \\ E-mail: deliya_poudel@hotmail.com
}




\section{INTRODUCTION}

Syringocystadenoma papilliferum (SCAP) is a rare benign hamartomatous adenexal tumor. Fifty percentof cases are present at birth or in early childhood, while another $15 \%-30 \%$ case develops during puberty. ${ }^{1}$ It typically involves the skin of head and neck. It can be associated with preexisting organoid nevus, sebaceous and other adenexal tumors. Clinical presentation varies widely but the histologic appearance is uniform and characteristic forming the basis of diagnosis. ${ }^{2} \mathrm{We}$ here present a case of syringocystadenoma papilliferum in deeper portion of neck in a 22 year female.

\section{CASE REPORT}

22 year female presented with complain of swelling in the right side of neck region for two years. Initially patient has lesion of $0.5 \mathrm{~cm} \times 0.5 \mathrm{~cm}$ which gradually progressed and was $4 \mathrm{~cm} \times 3 \mathrm{~cm}$ at the time of presentation. Swelling was firm, mobile, non tender. A presumptive diagnosis of cervical lymphadenopathy was made.

The patient was operated under local anaesthesia. Lesion was found just beneath the sternocleidomastoid muscle. Lesion was excised completely with a normal margin of $0.5 \mathrm{~cm}$. Postoperative period was uneventful.

\section{Histopathological Examination:}

Gross finding: single mass of tissue measuring $2.2 \mathrm{~cm} \times 0.7 \mathrm{~cm}$, black in colour, soft in consistency, cut surface show hemorrhagic area.

Microscopic findings: section showed features of sweat gland tumor with cystic spaces and papillary projections with areas of hemorrhage (Fig. 1). Papillary strands are lined by cuboidal to flattened epithelium forming complex papillary structure at places. The papillary core show dilated capillaries and contain dense lymphoid aggregates and plasma cells with areas showing apocrine metaplasia, focal dysplasia along with lymphocytes and macrophages within the connective tissue (Fig.1 and 2)

The final histopathological diagnosis was syringocystadenoma papilliferum.

\section{DISCUSSION}

Syringocystadenoma papilliferum is an exceedingly rare hamartomatous proliferative malformation derived from apocrine sweat glands of the skin. It usually appears at birth or during infancy or around puberty. ${ }^{1}$ In this case it started appearing at the age of 22 years.
Majority of SCAP arise on the head and neck. ${ }^{3}$ Other unusual reported location of SCAP includeseyelid, buttock, vulva and scrotum, outer ear canal, post-operative scar, thigh, axilla and back. $^{4}$

Early lesion appears as pink or skin coloured solitary nodules, or as grouped nodules. Verrucous and hyperkeratotic lesions can also occur. ${ }^{5}$ The lesion enlarge gradually, accelerated growth within a matter of month has also been described.

One third of all the cases arise in an organoid nevus, such as nevus sebaceous. ${ }^{3,6}$ Coexisting basal cell carcinoma is noted in $10 \%$ of cases. ${ }^{6}$ Syringocystadenocarcinoma papilliferum is the malignant counterpart characterized by solid areas and cytologically malignant cells. ${ }^{1}$

Figure 1: Shows numerous papillary infolding lined by cuboidal cells with cystic spaces epithelium and fibrovascular core with lymphocytes

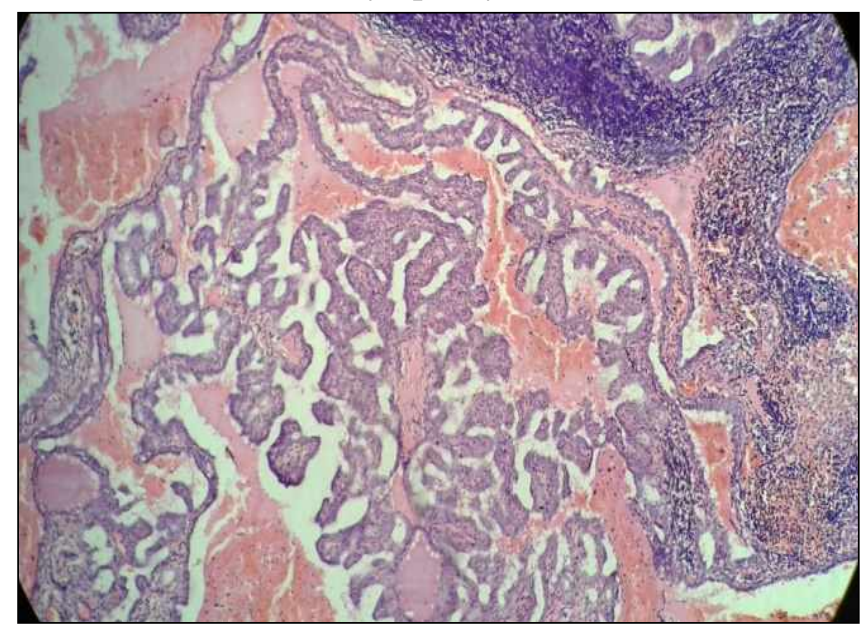

Figure 2: High power view shows papillary projections lined by low to flat cuboidal

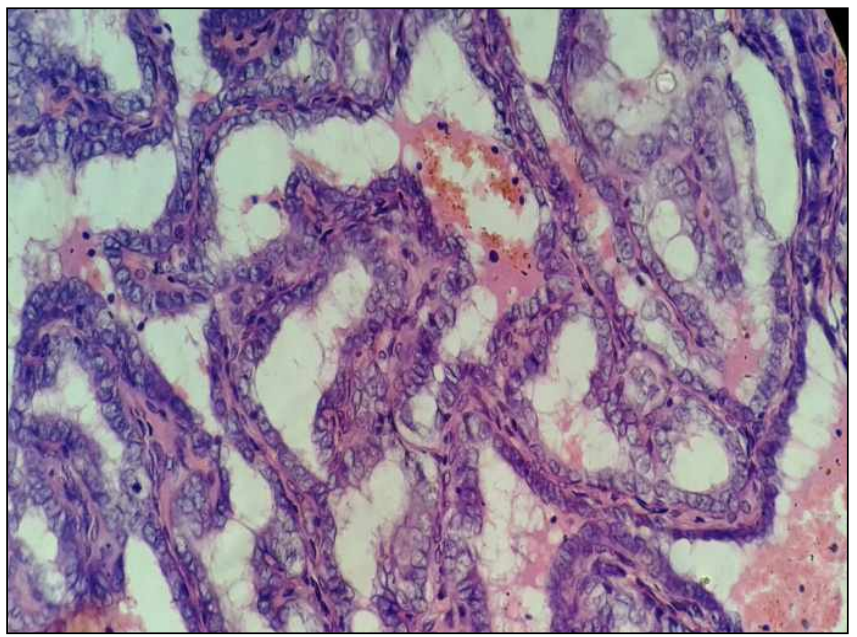


These papillary projections and lower portion of the invagination are lined by glandular epithelium typically consisting of two rows of cells. ${ }^{7}$ The inner luminal row consists of columnar cells and sometimes shows active decapitation secretion. ${ }^{8}$ One significant and diagnostic feature is the presence of a cellular infiltrate mainly composed of plasma cells within the stroma of this tumor particularly in the papillary projections with dilated capillaries. ${ }^{5,6,10}$

Although neck was the common site, in this case lesion was deeper to the sternocleidomastoid muscle which was the unusual site for SCAP. SCAP was not considered as a clinical diagnosis and was a histological surprise. Cervical lymphadenopathy was considered first as provisional diagnosis.

There were few studies which reported the case of SCAP in $\mathrm{leg}^{3}$, lower abdomen ${ }^{4}$, thigh $^{6}$ and our case was also at the unusual site, sternocleidomastoid muscle. Surgical excision with reconstruction is the treatment of choice for SCAP. ${ }^{11}$ Carbondioxide laser excision of SCAP of the head and neck is the clinical treatment option in anatomic areas unfavourable to excision and grafting. ${ }^{2,3}$ Radiotherapy and other destructive procedure are ineffective and best avoided. ${ }^{11}$

In conclusion, SCAP is rare neoplasm with apocrine differentiation. In the present case, lesion was diagnosed as SCAP after histopathological examination with foci of dysplasia which was a rarity. Solitary lesions although in usual location must be excised and sent for histopathological examination to avoid malignant transformation.

\section{REFERENCES}

1. Maychet M, Sangma B et al., SyringocystadenomaPapilliferum of the Scalp in an Adult Male A Case Report. Journal of Clinical and Diagnostic Research. 2013:7(4): 742-3

2. Elfatoiki F, Khadir K, Quakadi A et al., Syringocysadenoma Papilliferum: Unusual location. Dermatological online journal 2011;17(6): 7. PMid:21696687

3. Yoshii N, Kanekura T, Setoyama M, Kanzaki T. Syringocystadenomapapilliferum: report of the first case on the lower leg. J Dermatol. 2004 Nov; 31(11):939-42. PMid:15729871

4. Xu D, Bi T, Lan $H, Y u W$, Wang $W$, Cao $F$, Jin $K$. Syringocystadenomapapilliferum in the right lower abdomen: a case report and review of literature. Onco Targets Ther. 2013; 6:233-6. PMid:23569386 PMCid:PMC3615882

5. Barbarino $S$, McCormick SA, Lauer SA, Milman T. Syringocystadenomapapilliferum of the eyelid.
OphthalPlastReconstr Surg. 2009 May-Jun; 25(3):185-8. http://dx.doi.org/10.1097//OP.0b013e3181a39512PMid:1945 4927

6. Malhotra P, Singh A, Ramesh V. Syringocystadenomapapilliferum on the thigh: an unusual location. Indian $J$ DermatolVenereolLeprol. 2009 Mar-Apr; 75(2):170-2. http://dx.doi.org/10.4103/0378-6323.48664PMid:19293506

7. Elder ED, Elenistsas R, Johnsonns B, Murphy GF, Xu XX, editors. Tumors with apocrine differentiation. Lever's Histopathology of the Skin, 9th ed. London: Lippincott Williams \& Wilkins; 2004. P.894-5.

8. Ghosh SK1, Mandal RK, Bandyopadhyay D, Mukhopadhyay SM. Adult-onset linear syringocystadenomapapilliferum over the inguinal fold: a case report with emphasis on mast cell staining pattern. Dermatol Online J. 2012 Nov 15;18(11):16.

9. Mambo NC. Immunohistochemical study of the immunoglobulin classes of the plasma cells in papillary syringadenoma. Virchows Arch A PatholAnatHistol. 1982;397(1):1-6.

http://dx.doi.org/10.1007/BF00430888PMid:6293158

10. Weedon D. Weedon's Skin Pathology. 3rd ed. Philadelphia: Elservier;2010.

11. Godkhindi V, Meshram D, Deshpande S. SyringocystadenomaPapilliferum- Case Report. IOSR Journal of Dental and Medical Sciences. 2013;(1):43-6.

12. Mammino JJ, Vidmar DA. Syringocystadenomapapilliferum. IntJDermatol. 1991 Nov;30(11):763-6. http://dx.doi.org/10.1111/j.1365-4362.1991.tb04780.x http://dx.doi.org/10.1111/j.1365-4362.1991.tb04801.x PMid:1661711 